\title{
Membanding Teori Transformasi Generatif dan Systemic Functional Grammar; Telaah Kritis-Dialogis Antar Madzab Linguistik
}

Mohammad Andi Hakim

Jurusan Bahasa dan Sastra Arab

IAIN Syekh Nurjati andihakim@syekhnurjati.ac.id

\begin{abstract}
This paper describes the great tradition of thought that influence the development of linguistic discourse. Between the two of linguistic madhhab described in this article is the theory of generative transformation fronted by Noam Chomsky and systemic functional grammar theory initiated by MAK Halliday tradition of thought. The study, conducted a literature study, by using qualitative descriptive study. The data in this paper is a literacy data set obtained from books, articles and journals, as a secondary source to obtain an adequate explanation of the study. This study aims to find a dialogical relationship between the two great streams of linguistics, which although mutual criticism.
\end{abstract}

Keywords : Madzab, SFL, transformasi generatif

\section{Pendahuluan}

Teori yang dilahirkan oleh madzab transformasi generatif dan digawangi oleh Chomsky salah satunya menempatkan sintaksis sebagai hal yang bersifat primer, independen dari makna dan bunyi. Hal tersebut yang kemudian banyak melahirkan kritik terhadapnya, yang mengarah pada pemahaman bahwa seharusnya peran utama didalam bahasa adalah makna, dan seterusnya adalah sintaksis dan bunyi.Aliran ini juga menganggap bahwa tahapan pengetahuan bahasa terdiri dari dua hal, yakni performansi dan kompetensi. 
Selanjutnya, Chomsky merasa bahwa competence grammar bersifat mandiri dan lepas dari peran, serta tidak berasal dari makna. Grammar dianggap sebagai kemampuan dan pengetahuan ideal tentang bahasa yang telah dimiliki oleh manusia.Hal tersebut relevan dengan teorinya tentang sesuatu yang dimiliki oleh manusia secara innate yakni Universal Grammar (UG) dan Language Acquisition Devive (LAD).

Kritik yang mengarah pada argumentasi tersebut muncul dari beberapa aliran linguistic seperti Generative Semantics, Cognitive Grammar dan Functionalist. Beberapa sanggahan yang disuarakan dapat penulis uraikan dalam tulisan ini. Bahasa yang fokus pada peran makna dan interpretasi dari syntax serta sound menjadi salah satu argumen kritiknya. Selain itu, menurut beberapa aliran diatas bahwa grammar seharusnya lebih fokus pada performansi, berbeda dengan teori yang dikemukakan Chomsky, mengenai fokusnya pada peran kompetensi. Bahwa aliran-aliran diatas menolak pemikiran Chomsky yang menganggap kompetensi kebahasaan tidak berasal dari makna.

Seperti yang dikemukakan oleh ahli bahasa Functional Halliday yang cenderung menyajikan pemahaman bahwa bahasa tidak sematamata bersifat otonom, yang terdiri dari seperangkat aturan dan kaidah. Memahami prinsip kebahasaan lebih penting adalah dengan memahami penggunaan bahasa itu sendiri, yakni terkait dengan fungsi penggunaan bahasa dan pengaruh yang ditimbulkanya. Dengan kata lain pemahaman kebahasaan harus lebih fokus pada hakikat bahasa, makna, dan relasinya dengan pemikiran penutur.

Penelitian tentang pemikiran Halliday telah banyak dilakukan oleh para ilmuan. Salah satunya Gordon Wells yang mengkaji teori Halliday dan Vygotsky dan kontribusinya dalam pembelajaran bahasa. Keduanya memberikan kontribusi yang signifikan dalam merumuskan strategi pembelajaran bahasa yang ideal (Wells, 1994). Selain itu kajian yang dilakukan oleh Setiadi memberikan uraian sistematis tentang kontribusi pemikiran Noam Chomsky dalam pembelajaran bahasa yang komunikatif (Setiadi, 2011). 
Studi tentang implementasi pemikiran Chomsky dalam bahasa Al-Qur'an juga dilakukan oleh Wati Susiawati. Tulisanya membuktikan kontribusi teori Transformasi Generatif dalam kajian Bahasa Arab. Hasilnya, meskipun dengan tata bahasa yang lebih kompleks mampu diuraikan polanya menggunakan teori Chomsky (Susiawati, 2018). Sejalan dengan pemahaman terhadap teori tersebut, Bavali and Firooz Sadighi menguraikan secara lebih komprehensif dua teori tersebut. Analisis terthadap Universal Grammar dan Systemic Functionak Grammar memberian konklusi bahwa keduanya saling melengkapi dalam diskursus ilmu linguistik (Bavali \& Sadighi, 2008).

Parret didalam bukunya berjudul Discussing Language memberikan panduan teoretis secara umum tentang pemikiran dua tokoh tersebut dalam diskursus linguistik. Keduanya digambarkan memiliki persamaan dan perbedaan yang saling melengkapi (Parret, 1974). Hal ini berbeda dengan penelitian yang dilakukan oleh Yassir Nasanius. Penelitianya memberikan peringatan tentang kematian teori Universal Grammar Chomsky. Menurutnya, SFL menjadi teori baru dan dapat menyelesaikan masalah yang tidak mampu diselesaikan UG (Nasanius, 2015).

Beberapa penelitian diatas sesungguhnya telah mampu menyajikan fakta empiris dan logis mengenai konsep pemikiran dua Madzab linguistik tersebut. Namun, penelitian tersebut belum mampu menjelaskan perbadingan kedua pemikiran tokoh secara komprehensif dan radikal. Selanjutnya, penelitian terdahulu juga belum mampu menemukan kontribusi kedua Madzab tersebut secara faktual dan kontekstual. Uraian hanya berkutat pada defisini dan sejarah pemikiran semata, tidak bersifat aplikatif.

Hal tersebut yang kemudian melatar belakangi lahirnya kajian ini. Studi ini fokus pada dua hal, antara lain; konsep pemikiran Halliday dan Chomsky serta kontribusi riil didalam kajian bahasa. Sehingga penelitian ini merupakan pengembangan dari penelitian terdahulu tentang komparasi pemikiran Chomsky dan Halliday. Gap penelitian sebelumnya yang hanya mengungkapkan perbandingan konseptual teori ini dalam perkembangan kajian linguistik dilengkapi 
melalui penelitian ini. Penelitian ini menjadi referensi praktis dalam memahami dua teori tersebut.

\section{Metode Penelitian}

Studi ini menggunakan pendekatan deskriptif kualitatif untuk menemukan gambaran tentang pemikiran kedua tokoh linguistik tersebut secara radikal dan komprehensif. Seperti dinarasikan oleh Donald bahwa penelitian kualitatif bertujuan untuk menggambarkan dan mengklarifikasi pengalaman manusia didalam kehidupanya (Hakim, 2014). Inilah yang kemudian menjadi basis pemikiran untuk menemukan kesesuaian dan ketidaksesuaian dua pandangan tokoh tersebut. Teknik analisis yang digunakan adalah analisis kepustakaan (library research). Melalui analisis pustaka, penulis mengumpulkan beragam informasi-informasi yang berkaitan dengan teori TTG dan SFL. Tujuan dari penelitian ini adalah mengungkap bagaimana ajaran-ajaran dari dua madzab pemikiran linguistik tersebut mampu memberikan kontribusi dalam perkembangan diskursus linguistik modern.

\section{Hasil dan Pembahasan}

\section{a. Transformasi Generatif}

Chomsky dikenal merupakan seorang revolusioner dalam kajian linguistik. Dimulai dengan penerbitan bukunya yang berjudul 'Syntactic Structures' ahli matematika tersebut memperkenalkan konsep Transformasi Generatif (TG) dengan prinsip-prinsip yang dituliskanya dalam buku tersebut.Beberapa konsep yang menjadi inti dari gramatika transformasional adalah pembedaan antara kompetensi dan performansi, dan pembedaan antara struktur dalam dan struktur luar. Konsep lainnya adalah penggunaan berbagai aturan transformasi yang menandai adanya suatu perpindahan unsur dalam suatu klausa. Gramatika transformasi juga menggunakan analisis struktur frasadengan diagram pohon (Gumono, 2015).

Seperti diuraikan secara singkat dalam penjelasan diatas Chomsky membuat distingsi antara kompeten dengan perfomans. Yusuf didalam penelitianya menjelaskan bahwa Istilah kompeten mengacu kepada pengetahuan implisit bahasa dari si penutur (pengetahuan 
penutur mengenai kaidah-kaidah bahasa). Sedangkan istilah perfomansi mengacu kepada penggunaan bahasa secara aktual di dalam situasi konkrit.Ujaran aktual seorang penutur boleh jadi tidak gramatikal atau tidak lengkap karena dia lelah, atau terlalu senang, atau kurang perhatian (Teddy, 2012).

Chomsky mengidentifikasikan bahwa seorang ahli bahasa harus menentukan dari data perfomansi sistem pokok dari kaidahkaidah yang telah dikuasai oleh penutur-pendengar yang dia gunakan di dalam kalimat aktual. Performansi yang dimaksudkan disini tidak serupa dengan yang dikonstruksi oleh aliran fungsional, bahwa tindak berbahasa merepresentasikan selalu makna, bukan hanya mewakili kaidah-kaidah yang telah dipahami dibenak setiap penutur.

Chomsky mendefinisikan tata bahasa sebagai a device of some sort for producing the sentences of the language under analysis atau dengan kata lain bahasa merupakan sejenis alat untuk menghasilkan kalimat dalam bahasa dengan dasar analisis penutur. Dalam konteks ini, istlah producing yang berarti menghasilkan kemudian diidentikan dengan dengan membangkitkan (generating), sehingga berkembang didalam teori Chomsky dengan istilah tata bahasa "generative" (Teddy, 2012).

Transformasi generatif menguraikan bahwa terdapat beberapa hubungan jenis kalimat yang tidak bisa dijelaskan secara komprehensif melalui tradisi linguistik fungsional, seperti Halliday. Transformasi generatif yang dikemukakan oleh Chomsky menguraikan bahwa, transformasi dianggap sebagai proses perubahan satu kalimat ke dalam kalimat yang lain menjadi bentuk baru. Bahwa sebenarnya masing-masing bahasa hanya memiliki sedikit jenis-jenis kalimat sederhana, atau yang lazim disebut sebagai kalimat 'kernel'. Kemudian melalui kalimat sederhana tersebut penutur bahasa sebenarnya melakukan sejumlah proses transformasi standar.Sehingga munculah beragam tata bahasa yang merupakan produk transformasi yang berasal dari kompetensi penutur yang bersifat independen. 
Transformasi generatif menguraikan bahwa terdapat beberapa hubungan jenis kalimat yang tidak bisa dijelaskan secara komprehensif melalui tradisi linguistik fungsional, seperti Halliday. Transformasi generatif yang dikemukakan oleh Chomsky menguraikan bahwa, transformasi dianggap sebagai proses perubahan satu kalimat ke dalam kalimat yang lain menjadi bentuk baru. Bahwa sebenarnya masing-masing bahasa hanya memiliki sedikit jenis-jenis kalimat sederhana, atau yang lazim disebut sebagai kalimat 'kernel'. Kemudian melalui kalimat sederhana tersebut penutur bahasa sebenarnya melakukan sejumlah proses transformasi standar.Sehingga munculah beragam tata bahasa yang merupakan produk transformasi yang berasal dari kompetensi penutur yang bersifat independen.

Pelesapan atau penyisipan dan mampu menjelaskan setiap struktur kalimat. Lebih dari itu, teori generatif transformasional mengambil peran penting untuk menelaah tentang aspek kebahasaan yang dilihat dari perspektif unsur-unsur bahasa dan fungsi bahasa itu sendiri. Teori generatif memberikan peluang dalam mengkaji bahasa melalui tiga buah komponen penting didalamnya, antara lain komponen fonologis, sintaksis dan semantic.

\section{b. Tata Bahasa Fungsional}

Selanjutnya penulis mencoba menguraikan distingsi yang dihasilkan diantara dua madzab linguistik tersebut. Perbedaan dialogis ilmu yang sesungguhnya saling melengkapi dan memperjelas pandangan satu sama lain dalam kajian bahasa. Sehingga dalam perkembanganya kemudian keduanya menjadi dasar yang kokoh bagi pengembangan tradisi dan diskursus ilmu bahasa.Seperti dijelaskan oleh Halliday bahwa:

SFL emphasizes on semiotics, the code of language and how the utterances and texts specify all the meaning potentials, studies the functional and situational organization of language in the social context.It is concerned with how the speakers generate utterances and texts to convey their intended meanings through the "generalized metafunctions that relate language to the outside world where 
interactants and their social roles matter (Halliday $\mathcal{E}$ Matthiessen, 2004).

Penjelasan di atas mengisyaratkan fokus teori Halliday yang memandang bahasa tidak bersifat otonom dan lepas dari makna. Oleh karena itu, pandanganya tentang bahasa adalah sebuah sistem tanda yang harus dipahami berdasarkan fungsinya dalam domain sosial. Sehingga pandangan kritis Halliday menyajikan fakta yang berbeda dari Transformasi Generatif, karena kecenderunganya yang lebih fokus pada fungsi penggunaan bahasa (performansi) yang merepresentasikan budaya dan konteks sosial masyarakat tertentu.

Dengan kata lain, pandangan madzab ini menjelaskan bahwa bahasa adalah sistem arti, sistem bentuk dan ekspresi untuk merealisasikan arti bahasa tersebut. Kajian ini seperti uraian Gumono berdasarkan dua konsep yang mendasar dan membedakan Tatabahasa Fungsional Sistemik dari aliran linguistic lain, termasuk teori Chomsky yaitu (a) bahasa merupakan fenomena sosial yang wujud sebagai semiotic sosial dan (b) bahasa merupakan teks yang berkonstrual (saling menentukan dan merujuk) dengan konteks social (Gumono, 2015). Seperti diungkapkan dalam penelitian penulis (Hakim, 2014, p. 30) bahwa The relationship between text and social context is the construal which determines each other, the social context determines the text and the text to determine the social context.

Sehingga dengan demikian, kajian bahasa tidak dapat dilepaskan dari konteks sosial.Karena baik teks maupun konteks keduanya saling memberikan pengaruh dalam tindak berwacana. Sehingga Halliday menguraikan proses yang perlu diperhatikan dalam menganalisis sebuah bahasa. Seperti uraian penulis berikut:

With regard to the first functional sense, the function of language in human life involves three things: (1) describe or depict (ideational function), (2) exchange (interpersonal function), and (3) stringing (textual function) of human experience. The third function is called metafungsi language (metafunction), namely the function of language use (Hakim, 2014). 
Sehingga teorinya yang masyhur kemudian menjelaskan secara apik tentang metafungsi bahasa yang dituliskanya dalam $A n$ Introduction to Functional Grammar menyebut ketiga fungsi utama ini sebagai metafungsi ideasional, interpersonal, dan tekstual (Halliday \& Matthiessen, 2004). Pertama fungsi ideasional yang menunjukkan penggunaan bahasa untuk mengekspresikan pengalaman. Didalamnya terdapat dua hal yang terkait dengan representasi ini, yakni makna eksperiential yang mengkodekan pengalaman dan makna logis yang memperlihatkan hubungan-hubungan atau keterkaitan unsur berdasarkan nalar (logika), seperti hubungan SubjekPredikator-Komplemen,induk-pewatas, dan hubungan-hubungan yang tertuang dalam kelompok kata yang dikenal sebagai konjungsi.

Kedua, fungsi interpersonal yang dikatakan Halliday (Hakim, 2014) bahwa interpersonal function deals with the social and power relations among language users, It relates participant's situational roles to the discourse produced, artinya bahwa fungsi tersebut berkaitan dengan relasi kuasa dan sosial diantara pengguna bahasa, hal tersebut terkait pula dengan situasi partisipan didalam memproduksi wacana. Ketiga fungsi tekstual, yaknimenggunakan bahasa untuk mengorganisasikan pengalaman-pengalaman, makna-makna logis dan interpersonal ke dalam suatu koherensi dalam hal bahasa tutur dan tulisan, lurus menyeluruh adalah hal yang pentingpada pembelajaran bahasa bahwa kata-kata yang digunakan, dan cara membawakannya, atau secara lebih teknis kodekan, adalah makna-makna.

Melalui tiga fungsi diatas, kemudian Halliday menegaskan tentang relasi teks dengan konteks sosial yang lepas dari perhatian Chomsky dengan teori transformasi generatifnya. Relasi tersebut diuaraikan Yusuf tentang dua preposisi yang digunakan untuk melihat relasi teks dengan konteks, yakni konteks kebudayaan dan konteks situasi (Teddy, 2012). Koteks kebudayaan, dilihat sebagai hal yang penting dan dapat berpengaruh dalam mengahasilkan makna dalam wacana tertentu. Kemungkinan arti tersebut dapat dianalisis dengan menjelaskan beberapa hal antara lain Being 'siapa kita 'Doing 'apa yang kita lakukan' dan Saying 'apa yang kita katakan'. Ketiga hal tersebut dapat memperjelas keterkaitan antara konteks kebudayaan 
yang berpengaruh dalam teks yang dihasilkan oleh penutur bahasa tertentu.

Selanjutnya, adalah konteks situasi. Konteks Situasi bisa ditentukan melalui penggunaan variable register: field, tenor dan mode. Field mengacu pada apa yang sedang terjadi, yakni mencakup: Fokus aktivitas (hakikat aktivitas sosial) dan Fokus objek (pokok masalah). Jadi field menetapkan apa yang sedang terjadi dengan sebuah acuan yang ada (referent).

Tenor mengacu pada relasi-relasi sosial di antara mereka yang ambil bagian. Relasi-relasi ini bisa ditetapkan dengan istilah berikut: Status atau kekuasaan (peran agen, kawan sebaya atau relasi yang bersifat hirarkis), Pengaruh (derajat rasa suka, benci atau netral) dan Kontak (frekuensi, durasi dan intimasi kontak sosial). Mode mengacu pada bagaimana bahasa yang digunakan, apakah; Saluran komunikasi berbentuk spoken atau written. Bahasa yang digunakan sebagai mode dari tindakan atau refleksi (Teddy, 2012).

\section{c. TG Vis a Vis SFL}

Secara umum telah disajikan diatas tentang teori Chomsky yang memberikan ajaran dalam memahami bahasa secara transformatif. Konsep-konsep didalam teorinya, termasuk membedakan antara kompetensi dan performansi, yang kemudian Chomsky lebih cenderung memposisikan kompetensi sebagai hal yang independen dari makna dan interpretasi, serta performansi yang dijadikan sebagai hal yang diamati berasal dari pengetahuan si penutur. Selanjutnya ia juga membuat pembedaan antara struktur dalam (deep structure) dan struktur luar (surface structure) yang terkandung didalam bahasa. Selain itu, konsepnya yang mutakhir adalah penggunaan berbagai aturan transformasi yang menandai adanya suatu perpindahan unsur dalam suatu klausa.

Hal tersebut yang kemudian menciptakan revolusi baru dalam kajian linguistik, dengan melakukan kodifikasi dan notasi bahasa melalui kaidah-kaidah yang dapat dijadikan sebagai standar universal. Berbeda dengan Chomsky, teori Linguistik Fungsional Sistemik Halliday memberikan pelajaran tentang posisi makna 
sebagai hal yang tidak dapat dilepaskan dari komptensi maupun performansi dalam berbahasa.

Bahasa didefinisikan sebagai fenomena sosial yang terwujud sebagai semiotika sosial.Selain itu bahasa dianggap sebagai teks yang berkonstrual dengan konteks sosial. Fokusnya terhadap relasi antara teks dengan konteks tentu tidak dapat terlihat dari teori Transformasi Generatif. Lahirnya pemikiran tentang metafungsi bahasa, antara lain fungsi ideasional, interpersonal dan tekstual yang kemudian berkorelasi dengan term field, tenor dan mood. Menunjukkan bahwa pemaknaan terhadap wacana dapat ditelaah melalui ekpresi pengalaman penutur, relasi partisipan didalam aktivitas berwacana, dan penggunaan bahasa untuk mengorganisasikan ekpresi pengalaman, dan relasi interpersonal.

Gerot dan Wignell menguraikan bahwa salah satu jasa dari teori Systemic Functional Linguistics adalah lahirnya konsep transitifitas. Dalam menganalisis representasi makna yang terkandung pada sebuah klausa perlu dilihat dari participant dan circumstance yang dimiliki. Sehingga pemaknaan yang didapatkan memiliki kekuatan pembenaran yang ideal. Terdapat enam proses dalam aplikasi transitifitas, antara lain; material process, mental process, relational process, verbal process, behavioral process, and existential process (Garot, Linda, \& Wigne, 1994) .

Pemikiran Halliday tersebut yang kemudian mengilhami lahirnya teori analisis wacana kritis. Melihat bahasa bukan hanya sebagai satuan teks, melainkan menyentuh dimensi co-text dan konteks. Analisis wacana kritis mengkaji relasi-relasi antara wacana, kuasa, dominasi, ketidaksamaan sosial, dan menelaah permasalahanpermasalahan sosial (Hakim, 2016). Seperti analisis wacana kritis yang dikembangkan oleh Van Dijk mengamanatkan beberapa langkah analisis, antara lain analisis tekstual dan analisis kognisi sosial. Ketiga analisis menjadi pisau bedah untuk membongkar praktik kekerasan simbolik yang terjadi dalam pendidikan. 


\section{Simpulan}

Secara umum tulisan ini menguraikan tentang teori Chomsky yang memberikan ajaran dalam memahami bahasa secara transformatif. Konsep-konsep didalam teorinya membedakan antara kompetensi dan performansi. Chomsky lebih cenderung memposisikan kompetensi sebagai hal yang independen dari makna dan interpretasi, serta performansi yang dijadikan sebagai hal yang diamati berasal dari pengetahuan si penutur. Kontribusi revolusioner Chomsky dalam kajian linguistik adalah pada konsep kodifikasi dan notasi bahasa yang ditemukan. Sedangkan Halliday memandang bahasa tidak bersifat otonom dan lepas dari makna. Menurutnya, bahasa adalah sebuah sistem tanda yang harus dipahami berdasarkan fungsinya dalam domain sosial. Teori Halliday lebih fokus pada fungsi penggunaan bahasa (performansi) yang merepresentasikan budaya dan konteks sosial masyarakat tertentu.

\section{Referensi}

Bavali, M., \& Sadighi, F. (2008). Chomsky's Universal Grammar and Halliday's Systemic Functional Linguistics: An Appraisal and a Compromise. Pan-Pacific Association of Applied Linguistics, 12(1), 11-28.

Garot, Linda, \& Wigne, P. (1994). Making sense of functional grammar. Australia: Gerd Stabler.

Gumono. (2015). Implementasi Teori Linguistik Dalam Penyusunan Buku Ajar. In Prosiding Seminar Nasional Bulan Bahasa UNIB. UNIB.

Hakim, M. A. (2014). The Analysis of MAK Halliday's Theory of Systemic Functional Grammar and Its impact to Discourse Analysis and Genre Based Approach. Vision, 2.

Hakim, M. A. (2016). Mendobrak Konstruksi Islam Modern dalam Buku PAI dan Budi Pekerti SMA; Sebuah Praksis Kekerasan

Verbal. In LAMAS. Semarang: Universitas Diponegoro.

Halliday, M., \& Matthiessen, C. (2004). An Introduction to Functional Grammar. London: Arnold. 
Nasanius, Y. (2015). Lonceng Kematian Teori Tata Bahasa Universal? Masyarakat Linguistik Indonesia, 32(1).

Parret, H. (1974). George Lakoff. UC: Barkeley.

Setiadi, A. C. (2011). Pengajaran Bahasa Dengan Pendekatan Komunikatif: Analisis Atas Teori Transformatif-Generatif Noam Chomsky. At-Ta'dib, 4(1).

Susiawati, W. (2018). Implementasi Teori Chomsky Dalam Bahasa Alquran. Arabiyat, 5(2).

Teddy, Y. (2012). Komparasi Tradisi Linguistik Halliday Versus Tradisi Linguistik Chomsky. SM, 6(1).

Wells, G. (1994). The Complementary Contributions of Halliday and Vygotsky to a "Language-Based Theory of Learning. Linguistics And Education, 6, 41-90. 